\title{
Structural Characterization of an Enantiomerically Pure Amino Acid Imidazolide and Direct Formation of the $\beta$-Lactam Nucleus from an a-Amino Acid
}

\author{
Brian S. Gerstenberger, Jinzhen Lin, Yvette S. Mimieux, Lauren E. Brown, Allen G. Oliver, \\ and Joseph P. Konopelski ${ }^{*}$ \\ Department of Chemistry and Biochemistry, University of California, Santa Cruz, California. 95064
}

\begin{abstract}
Decomposition of a diazo $\beta$-ketoamide derived from $N$-trityl serine imidazolide and $N$-protected acetanilides provides, instead of the expected 3-acyloxindole product, an enantiomerically pure (EP) $\beta$-lactam. The amino acid stereocenter is incorporated, the second chiral center is induced and trityl protection of the $\beta$-lactam ring is realized for the first time. The desired 3-acyloxindole is obtained from oxindole and $\operatorname{Tr}-\mathrm{Ser}(\mathrm{OBn})$-imidazole, the $\mathrm{X}$-ray of which provides the first structural determination of an EP amino acid imidazolide.
\end{abstract}

Nitrogen heterocycles occupy a premier position in both natural product chemistry and pharmaceutical science, and both azetidin-2-ones ( $\beta$-lactams) and indoles are among the most investigated of such ring systems due to their well documented impact on small molecule drug discovery. In addition, enantiomerically pure (EP) $\beta$-lactams act as multifunctional organic motifs for the elaboration of more complex targets ${ }^{1}$ and as rigid $\beta$-turn scaffolds. ${ }^{2,3}$

Furthermore, the facile synthetic relationship between $\beta$-amino acids ${ }^{4}$ and $\beta$-lactams ${ }^{5}$ and the vibrant interest in polymers of EP $\beta$-amino acids (" $\beta$-foldamers" 6,7 ) ensures that research into this strained four-membered ring system will continue unabated.

For our synthesis 8 of the marine natural product diazonamide A (19) we required the construction of highly functionalized 3 -acyloxindole $\mathbf{2}$. Two approaches were conceived (Scheme 1). One sought direct acylation of the corresponding C3-unsubstituted oxindole (3, $\mathrm{PG}=$ protection group, $\mathrm{Y}=\mathrm{H}$ or halogen) with a serine derivative $(\mathrm{LG}=$ leaving group). The second route relied on diazo compound 4 , which would be subjected to $\mathrm{Rh}^{\mathrm{II}}$-catalyzed decomposition to promote $\mathrm{C}-\mathrm{H}$ insertion and oxindole formation as described by Doyle. ${ }^{10}$ Herein we report that each of these synthetic routes led to unexpected discoveries. The direct acylation route led to the first isolation and structural characterization of an EP amino acid imidazolide and culminated with the synthesis of $\mathbf{2}$. The $\mathrm{Rh}^{\mathrm{II}}$-catalyzed $\mathrm{C}-\mathrm{H}$ insertion route did not lead to 2, but rather to the first reported direct transformation of an EP $\alpha$-amino acid derivative to the $\beta$-lactam nucleus with complete retention of absolute stereochemistry and induction of the second ring chiral center.

The literature describes very few examples of oxindole acylation at $\mathrm{C} 3$ and no examples employing amino acids or their derivatives, some of which are prone to racemization. We were guided to trityl $(\mathrm{Tr})$ protection of the serine amine functionality $\left(\mathrm{PG}_{2}\right)$ for both routes to 2 by the body of work in this area from the Rapoport group and the documented chiral stability of such derivatives. ${ }^{11}$ It was also hoped (for the sequence of $\mathbf{4}$ to 2 ) that this protection scheme 
would prevent not only N-H insertion 12 of the reactive carbenoid to the amino acid nitrogen but also $\mathrm{C}-\mathrm{H}$ insertion into the serine side chain. The acid imidazolide was chosen for ease of preparation ${ }^{13}$ and compatibility with the acid-labile trityl group.

Oxindoles 3 were prepared from two different routes. $N$-Benzyloxindole (3a) was prepared from isatin by a recently published procedure. ${ }^{14}$ Unfortunately, the corresponding MOMprotected 7-bromoisatin did not produce desired material from this procedure nor was the $\mathrm{N}$ protection of 7-bromooxindole successful. Therefore, a more general and higher yielding route to $\mathbf{3 b}$ was developed that employed acetanilide $\mathbf{5}$, prepared in quantitative yield from 2bromoaniline (Scheme 2). Protection of $\mathbf{5}$ afforded $\mathbf{6}$ in excellent yield. The anion of $\mathbf{6}$ (LiHMDS) was reacted with 2,2,2-trifluoroethyl trifluoroacetate yielding the trifluoro- $\beta$ ketoamide, which could be converted without purification into 7 in $89 \%$ yield through diazo transfer $\left(\mathrm{MsN}_{3} / \mathrm{DBU}\right)$ and in situ ketone cleavage during workup (10\% $\left.\mathrm{NaOH}\right) .{ }^{15}$ This diazo compound underwent clean C-H insertion yielding $\mathbf{3 b}$ in $60 \%$ (50\% overall yield from 5).

Standard in situ ${ }^{13}$ reaction of $\mathrm{Tr}-\mathrm{Ser}(\mathrm{OBn})-\mathrm{OH}$ with $1,1^{\prime}$-carbonyldiimidazole (CDI, 1.05 equiv) afforded the expected solution of acid imidazolide $\mathbf{8}$ and imidazole, which was added directly to the anion of oxindoles $\mathbf{3 a}, \mathbf{b}$. Reaction yields were variable, and were ascribed to such factors as incomplete imidazolide formation, ${ }^{16}$ the presence of imidazole in the solution of acid imidazolide and difficulties in managing the reactive oxindole anion content in the presence of growing amounts of more acidic $\beta$-ketolactam product.

We postulated that isolation and purification of imidazolide $\mathbf{8}$, if possible, could be used to improve the yield. To this end, $\mathrm{Tr}-\mathrm{Ser}(\mathrm{OBn})-\mathrm{OH}$ was reacted with excess $\mathrm{CDI}$ (1.5 equiv) to ensure complete conversion, followed by aqueous workup to remove the excess CDI. We were both pleased and surprised to find that this acid imidazolide, obtained in $97 \%$ yield, was a stable crystalline solid that was easily purified by column chromatography on silica gel. ${ }^{17}$ Although a number of simple acid imidazolides have been shown to be isolable compounds, ${ }^{18}$ the literature, to our knowledge, makes no mention of EP amino acid imidazolide stability, although these reactive amides are used extensively in synthesis. ${ }^{19}$ Indeed, just the opposite appeared to be the case, as acid imidazolides are routinely prepared and immediately used without isolation because of their high reactivity. ${ }^{13} \mathrm{We}$ have also prepared stable crystalline acid imidazolides from Tr-Phe-OH and Tr-Val-OH.

A review of the Cambridge Crystal Structure Database reveals that there are very few examples of structurally characterized activated amino acid amide compounds. Compound $\mathbf{8}$ crystallizes in the chiral space group $\mathrm{C} 222_{1}$ (Figure 1). The position of the amine hydrogen, $\mathrm{H} 3$, was located from a difference Fourier map. It is oriented towards the imidazole nitrogen, N2, of an adjacent, symmetry-related molecule giving rise to one-dimensional chains of $\mathrm{H}$-bonded molecules running through the lattice parallel to the $a$-axis (N3...N2' distance $=3.3243(19) \AA$, see table of hydrogen-bonds). ${ }^{20}$ The structure in Figure 1 confirms that chirality is retained throughout the synthesis. The bond distances and angles within the molecule are comparable to other, similar compounds. ${ }^{21,22}$ For one of these studies ${ }^{21 b}$ it was speculated that the electrondonating properties of the trityl group stabilized the carbonyl to reaction by nucleophiles, whereas the more common carbamate protection groups for nitrogen are electron-withdrawing and activate the carbonyl.

With clean acid imidazolide $\mathbf{8}$ in hand, $C$-acylation under the previous conditions using the sodium anion of $\mathbf{3}$ provided a $10 \%$ increase in yield (Table 1, entry 5). The problem of reactive anion management was solved by employing lithium imidazolide as base rather than the preformed anion of $\mathbf{3}$. This final optimization led to a reproducible $72 \%$ yield of desired product 2. 
Success in the transformation of $\mathbf{7}$ to $\mathbf{3 b}$ via the $\mathrm{Rh}^{\mathrm{II}}$-catalyzed $\mathrm{C}-\mathrm{H}$ insertion reaction offered us excellent precedent for our second route to $\mathbf{2}$; namely, diazo decomposition of $\mathbf{4}$. Compounds $\mathbf{4 a}, \mathbf{b}$ were synthesized by acylation of the anions derived from $N$-benzylacetanilide and $\mathbf{6}(\mathrm{NaH})$ using in situ generated imidazolide $\mathbf{8}$, which gave the $\beta$-ketoamides in $45-55 \%$ yield (Scheme 3). Treatment with mesyl azide $\left(\mathrm{MsN}_{3}\right)^{23}$ or 4-acetamidobenzenesulfonyl azide with DBU gave the desired diazo compounds $\mathbf{4 a , b}$ in $89 \%$ and $96 \%$ yield, respectively. However, no oxindole was observed upon rhodium-catalyzed diazo decomposition. Unexpectedly, we obtained the trans-trityl-protected $\beta$-lactam. The structure of trans isomer 9 was confirmed by $\mathrm{X}$-ray crystallography. The trans isomer $\mathbf{1 1}$ was isolated in $60 \%$ yield by treatment with the rhodium catalyst.

This unexpected and unprecedented route to the $\beta$-lactam nucleus directly from an $\alpha$-amino acid, to our knowledge the first documented transformation of its kind, is best explained mechanistically by invoking a stereospecific Wolff rearrangement ${ }^{24}$ to form ketene intermediate 12, which undergoes intramolecular attack by the trityl-protected amine. Intramolecular ring closures of $N$-trityl groups have been observed previously. ${ }^{25}$ Wolff rearrangements catalyzed by $\mathrm{Rh}(\mathrm{II})$ species are rare, but have been documented. ${ }^{26}$ Furthermore, this appears to be the first known synthesis of a trityl protected $\beta$-lactam amide, as a recent effort to add a trityl group to the 4-membered lactam afforded poor yield. ${ }^{27}$

To support this mechanism, diazoketones 4 were decomposed with silver benzoate, ${ }^{28}$ a wellknown reagent for the Arndt-Eistert elongation of $\alpha$ - to $\beta$-amino acids, and with UV radiation. ${ }^{29}$ Desired lactams 9-11 were isolated from each reaction, which supports the Wolff rearrangement pathway (through 12) in the metal-catalyzed transformation. The cleanest and highest yielding reactions were photochemical. Upon irradiation, compound 4a gave a 2.5:1 separable mixture of trans and cis $\beta$-lactam isomers, respectively, in $76 \%$ yield. Comparison with the rhodium-catalyzed reaction (vide supra) revealed the presence of the cis isomer in the former reaction. However, only the trans isomer ( $88 \%$ yield) was isolated from irradiation of 4b (Scheme 3, box). Wolff rearrangements generally proceed with retention of configuration; 30 this was verified for 9 by refinement of the X-ray data ${ }^{31}$ (Flack parameter $=0.04$ (11)). In addition, we have shown that the reaction is completely stereospecific; i.e., D-Tr-Ser(OBn)imidazole (ent-8) affords the enantiomeric material ent-9 as shown by chiral column HPLC; there is no indication of enantiomer formation in either reaction.

Questions concerning the origin and scope of this unexpected Wolff rearrangement, in contrast to $\mathrm{N}-\mathrm{H}$ or $\mathrm{C}-\mathrm{H}$ insertion, the utility of trityl protection of the $\beta$-lactam amide functionality and the facile access to stable crystalline amino acid imidazolides in high yield are currently under study in our laboratory and will be reported in due course.

\section{Supplementary Material}

Refer to Web version on PubMed Central for supplementary material.

\section{Acknowledgment}

We wish to thank the NIH (CA98878) for generous support of this work. In addition, we thank the ACS-PRF Summer School, "Crystallography for Organic Chemists" for the opportunity for one of us (LEB) to particpate and collect the data for 9. Purchase of the $600 \mathrm{MHz}$ NMR used in these studies was supported by funds from the National Institutes of Health (S10RR019918) and National Science Foundation (CHE-0342912).

\section{References}

1. Alcaide B, Almendros P. Chem. Soc. Rev 2001;30:226-240.

2. Maier TC, Frey WU, Podlech J. Eur. J. Org. Chem 2002:2686-2689. 
3. Palomo C, Aizpurua JM, Balentová E, Jimenez A, Oyarbide J, Fratila RM, Miranda JI. Org. Lett 2007;9:101-104. [PubMed: 17192095]

4. Juaristi, E. Enantioselective Synthesis of $\beta$-Amino Acids. New York: Wiley-VCH; 1997. Juaristi, E.; Soloshonok, V. Enantioselective Synthesis of $\beta$-Amino Acids. 2nd ed.. New York: Wiley; 2005.

5. a) Palomo C, Aizpurua JM, Ganboa I. Chapter 14. The Synthesis of $\beta$-Amino Acids and Their Derivatives from $\beta$-Lactams. in reference $4 \mathrm{a}$ b) Palomo C, Aizpurua JM, Ganboa I, Oiarbide M. Chapter 20. The Synthesis of $\beta$-Amino Acids and Their Derivatives from $\beta$-Lactams: Update. in reference $4 b$

6. a) Gelman MA, Gellman SH. Chapter 22. Using Constrained $\beta$-Amino Acid Residues to Control $\beta$ Peptide Shape and Function. in reference $4 b$ b) Campo MA, Escalante J, Šebesta R. Chapter 23. $\beta$ Amino Acids with Proteinogenic Side Chains and Corresponding Peptides: Synthesis, Secondary Structure, and Biological Activity. in reference $4 \mathrm{~b}$

7. Seebach D, Kimmerlin T, Šebesta R, Campo MA, Beck AK. Tetrahedron 2004;60:7455-7506.

8. Konopelski JP, Hottenroth JM, Mónzo-Oltra H, Véliz EA, Yang Z-C. Synlett 1996:609-611.

9. a) Lindquist N, Fenical W, Van Duyne GD, Clardy J. J. Am. Chem. Soc 1991;113:2103-2304. b) Li J, Jeong S, Esser L, Harran PG. Angew. Chem. Int. Ed 2001;40:4765-4769.Angew. Chem 2001;113:4901-4904. c) Li J, Burgett AWG, Esser L, Amezcua C, Harran PG. Angew. Chem. Int. Ed 2001;40:4770-4773.Angew. Chem 2001;113:4905-4909.

10. Doyle MP, Shanklin MS, Pho HQ, Mahapatro SN. J. Org. Chem 1988;53:1017-1022.

11. Sim TB, Rapoport H. J. Org. Chem 1999;64:2532-2536.

12. a) Ferris L, Haigh D, Moody CJ. J. Chem. Soc., Perkin Trans. 1 1996:2885-2888. b) Aller E, Buck RT, Drysdale MJ, Ferris L, Haigh D, Moody CJ, Pearson ND, Sanghera JB. J. Chem. Soc., Perkin Trans. 1 1996:2879-2884.

13. Brooks DW, Lu LD-L, Masamune S. Angew. Chem. Int. Ed. Engl 1979;18:72-74. [PubMed: 105650]

14. Marti C, Carreira EM. J. Am. Chem. Soc 2005;127:11505-11515. [PubMed: 16089481]

15. Doyle MP, Dorow RL, Terpstra JW, Rodenhouse RA. J. Org. Chem 1985;50:1663-1666.

16. Morton RC, Mangroo D, Gerber GE. Can. J. Chem 1988;66:1701-1705.

17. For a previous synthesis of 8, without isolation, see Hoffman RV, Tao J. J. Org. Chem 1999;64:126132. [PubMed: 11674093]

18. Staab HA. Angew. Chem. Internat. Edit 1962;1:351-367.

19. Staab, HA.; Bauer, H.; Schneider, KM. Azolides in Organic Synthesis and Biochemistry. New York: Wiley-VCH; 1998.

20. The crystal structure for $\mathbf{8}$ has been deposited at the Cambridge Crystallographic Data Center and allocated the reference no. 655083 .

21. a) Barlos K, Papaioannou D, Voliotis S, Prewo R, Bieri JH. J. Org. Chem 1985;50:696-697. b) Sliedregt KM, Schouten A, Kroon J, Liskamp RMJ. Tetrahedron Lett 1996;37:4237-4240. c) Mamos P, Papaioannou D, Kavounis C, Nastopoulos V. Acta. Cryst 1997;C53:1973-1975.

22. The crystal structure of achiral Tos-MeAib-Im has been reported. See a) Toniolo C, Crisma M, Formaggio F. Biopolymers 1996;40:627-651. b) Crisma M, Moretto V, Formaggio F, Toniolo CZ. Kristallogr 1999;214:766-770.

23. Taber DF, Ruckle RE, Hennessy MJ. J. Org. Chem 1986;51:4077-4078.

24. Kirmse W. Eur. J. Org. Chem 2002:2193-2256.

25. May JP, Fournier P, Pellicelli J, Patrick BO, Perrini DM. J. Org. Chem 2005;70:8424-8430. [PubMed: 16209587]

26. Davies JR, Kane PD, Moody CJ, Slawin AMZ. J. Org. Chem 2005;70:5840-5851. [PubMed: 16018676] and references therein

27. Reddy DR, Iqbal MA, Hudkins RL, Messina-McLaughlin PA, Mallamo JP. Tetrahedron Lett 2002;43:8063-8066.

28. Sudrik SG, Maddanimath T, Chaki NK, Chavan SP, Chavan SP, Sonawane HR, Vijayamohanan K. Org. Lett 2003;5:2355-2358. [PubMed: 12816447] and references therein

29. Podlech J, Seebach D. Angew. Chem. Int. Ed. Engl 1995;34:471-472. 
30. Doyle, MP.; McKervey, MA.; Ye, T. Modern Catalytic Methods for Organic Synthesis with Diazo Compounds. Wiley-Interscience; 1998. p. 498ff

31. The crystal structure for $\mathbf{9}$ has been deposited at the Cambridge Crystallographic Data Center and allocated the reference no. 655084 . 


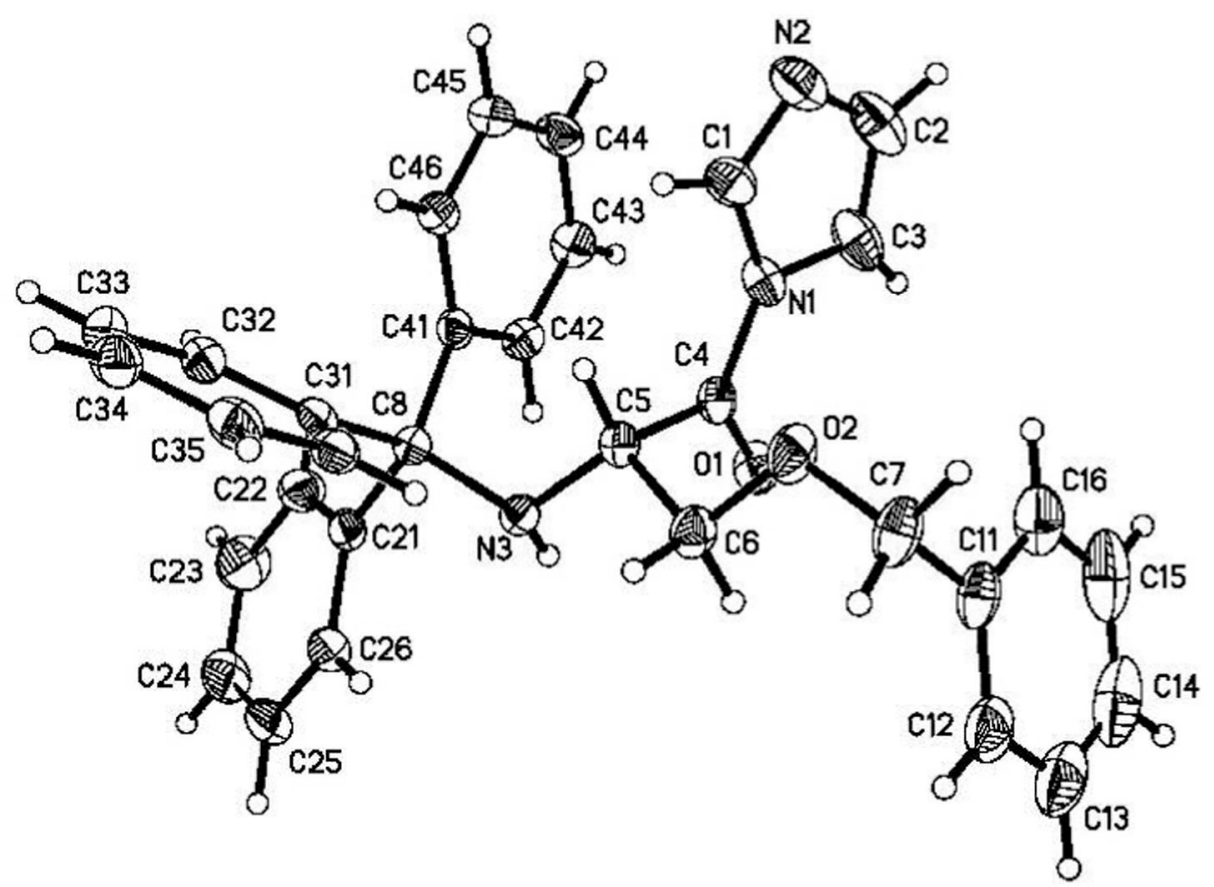

Figure 1.

Solid state structure of acid imidazolide $\mathbf{8}$. 


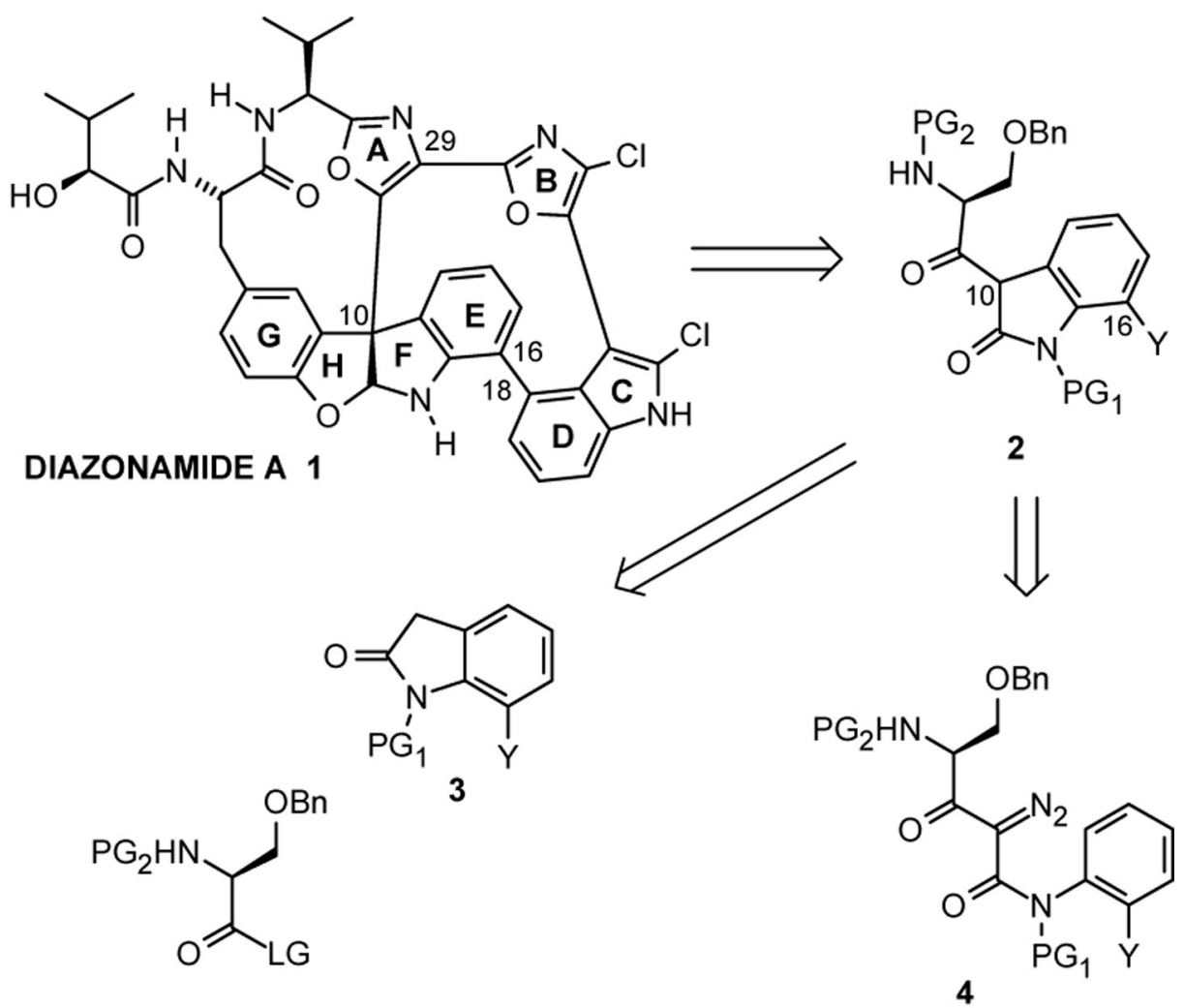

Scheme 1.

Diazonamide A retrosynthesis 


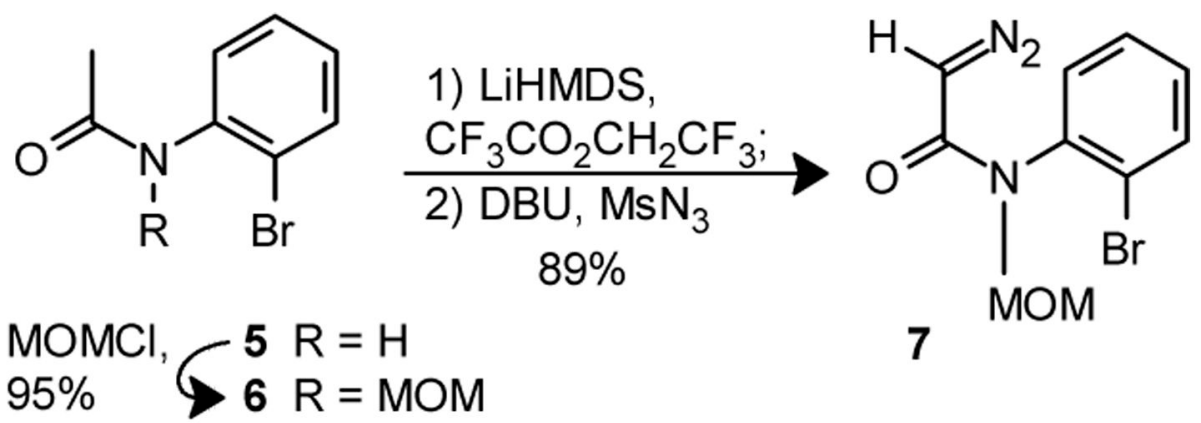

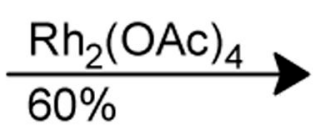<smiles>CON1C(=O)Cc2cccc(Br)c21</smiles>

3b

Scheme 2.

Oxindole preparation 


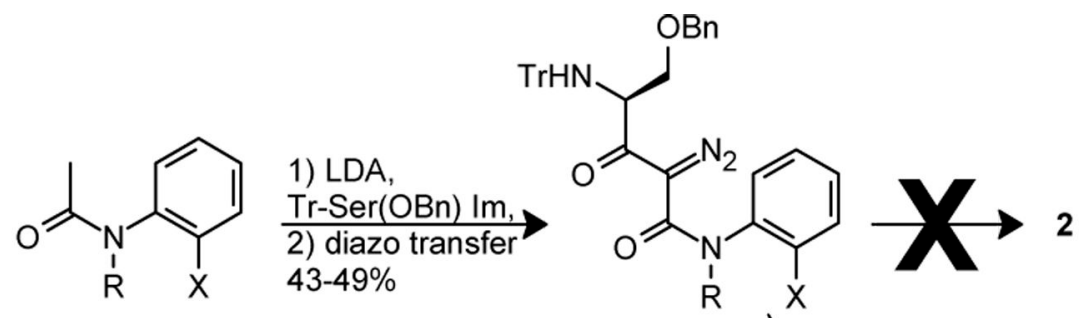

$$
\mathrm{R}=\mathrm{Bn}, \mathrm{X}=\mathrm{H}
$$

$6 \mathrm{R}=\mathrm{MOM}, \mathrm{X}=\mathrm{Br}$

4a $R=B n, X=H$

4b $\mathrm{R}=\mathrm{MOM}, \mathrm{X}=\mathrm{Br}$

$\mathrm{Rh}_{2}\left(\mathrm{NH}(\mathrm{O}) \mathrm{CCF}_{3}\right)_{4}$

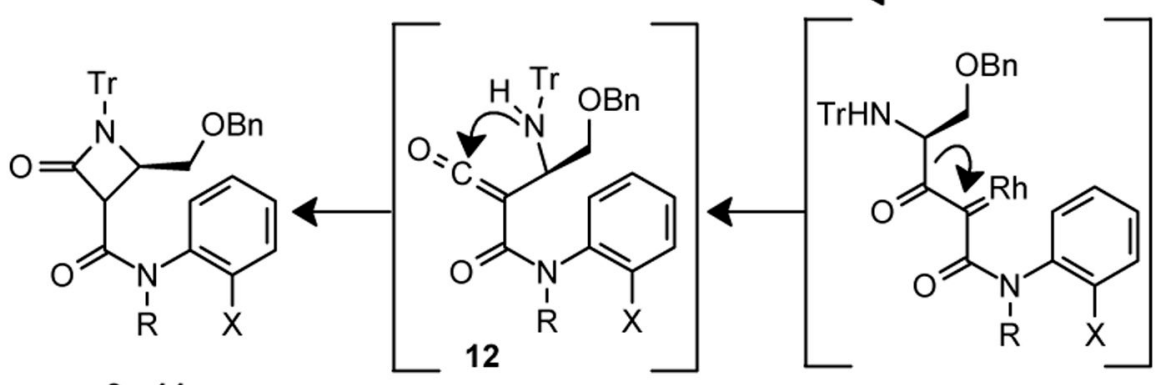

9 - 11<smiles>CCCOc1ccccc1</smiles>

9

$\mathrm{Rh}$ (II) catalysis - $48 \%$ h $v-54 \%$<smiles>[3H]N1C(=O)[C@@H](C(=O)N(Cc2ccccc2)c2ccccc2)[C@@H]1COCc1ccccc1</smiles>

10

hv $-22 \%$<smiles>[CH]N1C(=O)[C@@H](C(=O)N(CC)c2ccccc2Br)[C@H]1COc1ccccc1</smiles>

$\mathrm{Rh}$ (II) catalysis - $60 \%$ $\mathrm{h} v-88 \%$

Scheme 3.

Wolff rearrangement to $\beta$-lactam 
Table 1

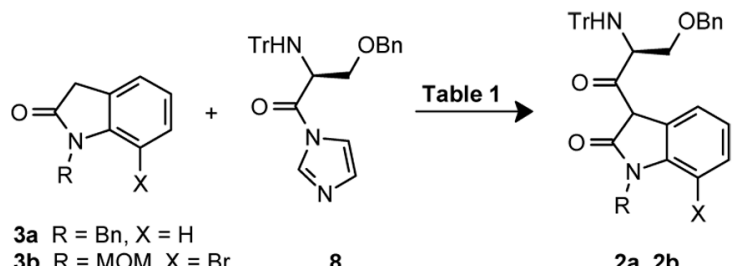

3b $\mathrm{R}=\mathrm{MOM}, \mathrm{X}=\mathrm{Br} \quad 8 \quad 2 \mathrm{a}, \mathbf{2 b}$

\begin{tabular}{|c|c|c|c|c|}
\hline entry & oxindole & base (equiv) & 8 & yield \\
\hline 1 & $\mathbf{3 a}$ & $\mathrm{NaH}(1.0)$ & In situ & $42 \%$ \\
\hline 2 & $\mathbf{3 a}$ & $\mathrm{NaH}(4.0)$ & In situ & $50 \%$ \\
\hline 3 & $\mathbf{3 b}$ & $\mathrm{NaH}(2.0)$ & In situ & $50 \%$ \\
\hline 4 & $\mathbf{3 b}$ & LDA (2.0) & In situ & $40 \%$ \\
\hline 5 & $\mathbf{3 b}$ & $\mathrm{NaH}(2.0)$ & Isolated & $60 \%$ \\
\hline 6 & $3 b$ & Li-imidazolide(2.0) & Isolated & $70 \%$ \\
\hline 7 & $3 \mathbf{b}$ & Li-imidazolide (5.0) & Isolated & $72 \%$ \\
\hline
\end{tabular}

Org Lett. Author manuscript; available in PMC 2009 February 7. 